\title{
SEed LoNGevity OF Red RICE ECOTYPES BuRIEd IN SOIL ${ }^{1}$
}

\author{
Longevidade de Sementes de Arroz-Vermelho Enterradas no Solo \\ NOLDIN, J.A. ${ }^{2}$, CHANDLER, J.M. ${ }^{3}$ and McCAULEY, G.N. ${ }^{4}$
}

\begin{abstract}
Red rice is a troublesome weed in irrigated rice production and is spread through contaminated commercial rice seed and machinery. Seed dormancy is a major trait for red rice. Studies were carried out at two locations to determine red rice seed longevity in the soil of several ecotypes from four US states. Five months after burial near Beaumont, Texas only three ecotypes had viable seed $(<1 \%)$ when buried at $5 \mathrm{~cm}$, but 9 ecotypes had viable seed after two years when buried at $25 \mathrm{~cm}$. At the thirty-sixth month after burial, ecotypes Arkansas 2 , Louisiana 2 and 4, Mississippi 4 and Texas 1 had viable seeds, but at less than 1\%. Freshly harvested red rice seeds buried at $12 \mathrm{~cm}$ near College Station, TX, survived longer than seeds placed on the soil surface. The percentage of maximum viable seeds was $2 \%$ for blackhull type Texas 4 , after 17 months. In both studies, commercial rice cultivar seeds were not viable after 5 months, regardless of their position in the soil. Under farming conditions with no fallow land preparations or deep tillage, most red rice seed germinated or was dead after 2 to 3 years, with only minor variation among ecotypes.
\end{abstract}

Keywords: $\quad$ red rice, Oryza sativa, rice, seed survival, seed dormancy, strawhull ecotypes, blackhull ecotypes.

RESUMO - O arroz-vermelho constitui-se na principal planta daninha infestante de lavouras de arroz irrigado e a sua disseminação ocorre, principalmente, pelo uso de sementes comerciais contaminadas e equipamentos agrícolas. A ocorrência de dormência nas sementes é uma das principais características que dificultam o controle do arroz-vermelho em lavouras. $O$ objetivo deste trabalho foi estimar a longevidade no solo de ecótipos de arroz-vermelho provenientes de diferentes áreas de produção de arroz nos Estados Unidos. O estudo foi conduzido em dois locais: Beaumont e College Station, no estado do Texas (TX). Para sementes enterradas a $5 \mathrm{~cm}$ de profundidade em Beaumont, apenas três ecótipos apresentaram sementes viáveis (<1\%). No entanto, quando as sementes foram enterradas em maior profundidade $(25 \mathrm{~cm})$, nove ecótipos tinham sementes viáveis após 2 anos. Trinta e seis meses após o enterrio, cinco ecótipos apresentavam sementes com alguma viabilidade, mas todos inferiores a 1\%. Sementes de arrozvermelho produzidas e enterradas em College Station na profundidade de $12 \mathrm{~cm}$, um dia após a colheita, apresentaram maior longevidade que aquelas mantidas na superficie do solo. Após 17 meses, um dos ecótipos de arroz-preto (TX 4), enterrado a $12 \mathrm{~cm}$, foi o que apresentou maior percentual de viabilidade (2\%). Nos dois experimentos, observou-se que os cultivares comerciais, Lemont e Mars, não apresentaram sementes viáveis após cinco meses, independentemente da localização no solo. Os resultados deste estudo sugerem que em áreas com arroz-vermelho deve-se evitar o preparo do solo logo após a colheita, favorecendo assim a germinação ou a perda da viabilidade das sementes. O enterrio das sementes de arroz-vermelho, através de operações de preparo do solo, contribui para aumentar o banco de sementes e a longevidade no solo.

Palavras-chave: arroz-daninho, arroz-preto, Oryza sativa, sobrevivência de sementes, dormência de sementes.

Recebido para publicação em 28.6.2006 e na forma revisada em 10.11.2006.

Pesquisador da Estação Experimental de Itajaí, Epagri, Caixa Postal 277, 88301-970, Itajaí, SC, <noldin@epagri.rct-sc.br>. ${ }^{3}$ Professor, Department of Soil and Crop Science, Texas A\&M University, College Station, TX, USA, 77843-2474. ${ }^{4}$ Professor, Texas A\&M Agricultural Research and Extension Center, Eagle Lake, TX, USA, 77434. 


\section{INTRODUCTION}

Red rice is a troublesome weed in rice growing areas in the southern United States and worldwide. Red rice can be spread as a contaminant of commercial rice seed and becomes very difficult to control. Preharvest seed shattering and dormancy are some traits commonly observed in most red rice populations which contribute to species survival strategy.

Weed seed persistence in the soil is a common trait. Seeds of many weed species can remain viable in the soil longer than 10 years (Toole \& Brown, 1946; Lewis, 1973; Dawson \& Bruns, 1975; Conn \& Deck, 1995; Burnside et al., 1996), some for up to 90 years (Kivilaan \& Bandurski, 1973) and other species, for over 120 years (Telewski \& Zeevaart, 2002). Seed longevity of annual grass weeds is generally shorter than broadleaf and perennial weed seeds (Burnside et al., 1996). A large number of weed seed longevity studies (Lewis, 1973; Dawson and Bruns, 1975; Egley \& Chandler, 1983; Conn \& Deck, 1995; Burnside et al., 1996) has been conducted throughout the world, but only a few included red rice. The only long-term seed longevity studies reported for red rice was conducted in the United States by Goss and Brown in the 1930's (Goss \& Brown 1939, 1940).

Several factors are involved in red rice seed longevity in soil. Goss \& Brown (1939, 1940) found that commercial rice cultivar seeds were viable for less than two years in three studies conducted in Stuttgart, AR, Beaumont, TX, and Biggs, CA. However, two red rice ecotypes from southern United States had more than 20\% viable seeds in Arkansas after burial at $17 \mathrm{~cm}$ for 10 years. Flooding during the rice growing season increased red rice seed longevity under Arkansas and Texas conditions, but the reverse occurred in California.

Seed dormancy affects seed longevity in many weed species (Taylorson, 1970; Zorner et al., 1984) and also in red rice (Goss \& Brown, 1940; Garcia-Quiroga, 1987). Baskin \& Baskin (1985) found a seasonal cycle in red rice dormancy. Seed dormancy in red rice ecotypes diminished significantly after seed burial in soil during the winter but rebounded to 90 to $98 \%$ dormancy in the summer. Non-dormant red rice seeds conditioned to $18.3 \%$ moisture content and stored for two months at 20 to $30{ }^{\circ} \mathrm{C}$ developed a secondary dormancy of more than 85\% (Garcia-Quiroga, 1987). Burial depth is another factor that affects seed longevity in soil. In general, seed longevity is greater as seeds are placed deeper in the soil (Miller \& Nalewaja, 1990).

Information about red rice seed longevity in soil is important for development of long term management programs that will reduce the soil seedbank population (Egley \& Williams, 1990). The objectives of this study were to evaluate the effects of burial depth, irrigation, and harvest time on seed longevity in soil for several red rice ecotypes from different areas and two commercial rice cultivars.

\section{MATERIALS AND METHODS}

\section{Beaumont experiment}

The experiment was designed to study the influence of irrigation, burial depth and red rice ecotypes on seed longevity in soil. Samples of red rice seeds were obtained from Arkansas (AR), Louisiana (LA), Mississippi (MS), and Texas (TX) in the spring of 1992. In that summer, seeds were planted near College Station, TX (30E 32.33' N, 96E 25.86' W). After harvesting, seeds were stored at room temperature $\left(20\right.$ to $\left.22{ }^{\circ} \mathrm{C}\right)$. Red rice ecotypes included blackhull types (AR 2, LA 4, TX 2), strawhull (LA 2, MS 1, MS 2, MS 5), goldhull (TX 1) and brownhull (MS 4). Commercial rice cultivars Lemont and Mars were included for comparison.

One hundred seeds of each red rice ecotype and commercial cultivar were mixed with $35 \mathrm{~g}$ of sieved ( $2 \mathrm{~mm})$ air dried Beaumont clay soil (51\% clay, $32 \%$ silt and $17 \%$ sand), $1.6 \%$ organic matter and pH 5.5) and placed into 6 by $9 \mathrm{~cm}$ 125-mesh polypropylene cloth (Nitex by Tetko Inc., Elmsford, NY) packets.

The packets were buried at 5 and $25 \mathrm{~cm}$ depths at the Texas A\&M Agricultural Research and Extension Center, near Beaumont, TX (30E 04.57' N, 94E 17.41' W), on March 17, 1993. Irrigation consisted of two treatments: plots managed as a fallow system receiving just rainfall or plots flooded to a depth of 10 
to $15 \mathrm{~cm}$ as for a rice crop for 8 to 10 weeks, every year from June to August. The soil was undisturbed and maintained bare throughout the study by periodic applications of glyphosate, $\mathrm{N}$-(phosphonomethyl) glycine, at $1.12 \mathrm{~kg}$ ai ha-1.

The experimental design used was a splitsplit-plot arrangement within a randomized complete block design with four replications. Irrigation treatments were the whole plots, burial depths as split plots, and red rice ecotypes/rice cultivars as split- split plots.

Seed samples were exhumed in August 1993, March and August 1994 and 1995, and March 1996, at 5, 12, 17, 24, 29 and 36 months after burial. Recovered seeds were washed free of soil and placed into $9 \mathrm{~cm}$ diameter Petri dishes containing moistened filter paper and incubated for 14 days at $30^{\circ} \mathrm{C}$ in the dark. The germinated seeds were then counted and removed. Viability of the remaining seeds was determined using the tetrazolium $(2,3,5$ triphenyltetrazolium chloride) test (Overaa, 1984). Seed embryos were cut longitudinally and a staining solution ( $1 \%$ tetrazolium) was added to cover all seeds. Dishes were placed in a growth chamber at $30{ }^{\circ} \mathrm{C}$ for three hours. Seeds with red or pink embryos were considered dormant. The percent of viable seeds was determined by adding the percent of seed that germinated to the percent of dormant seeds determined as viable by the tetrazolium test.

\section{College Station experiment}

This experiment was established to evaluate the effect of red rice ecotype/rice cultivar, seed dormancy level and seed burial depth on longevity of red rice in soil. Red rice ecotypes included blackhull (AR 2, LA 4, TX 2, TX 4), strawhull (LA 2, MS 1, MS 2, MS 5, MS 6), goldhull (TX 1), and brownhull (MS 4), and two commercial rice cultivars (Lemont and Mars). Seed stock plots were planted at the Agronomy Farm near College Station, TX (30E 32.33' N, 96E 25.86' W), in 1993. A six-row plot for each rice type was established by transplanting 2-3 leaf seedlings established in the greenhouse. Seedlings were spaced $10 \mathrm{~cm}$ apart in the row with $50 \mathrm{~cm}$ between rows resulting in 3 by $5.5 \mathrm{~m}$ plots. Plots were isolated from adjacent plots by at least $0.5 \mathrm{~m}$. Irrigation, fertilization and other cultural practices followed standard recommendations for rice in Texas. Visually detected off-type plants were removed during the growing season. At the beginning of the heading stage, the experimental area was covered with nylon nets to avoid bird damage.

At anthesis, when approximately 50\% of the florets on a panicle had flowered, about 200 panicles from each plot were tagged. To avoid early seed shattering, panicles of all red rice ecotypes, except MS 5, were placed in white 'popcorn type' paper bags 8-10 days after anthesis. Ecotype MS 5 was not bagged because it does not shatter. Research has shown that bagging did not effect seed germination or dormancy (Yoshida, 1981).

Fifty to sixty randomly selected tagged panicles were harvested at 15, 30 and 45 days after anthesis. Panicles were threshed and seeds were placed in a barley de-awner for about 30 seconds to remove the awns. The seed samples were then cleaned by screening and aspiration. In the laboratory, germination and dormancy were determined on the same day using four replications of 50 seed lots for each red rice ecotype/rice cultivar (as described for the previous experiment).

One hundred freshly harvested seeds collected 15, 30 and 45 days after anthesis were mixed with about $35 \mathrm{~g}$ of sieved $(2 \mathrm{~mm})$ air dried shipps clay soil (83\% clay, 17\% silt, $2.4 \%$ organic matter, and $\mathrm{pH} 7.8$ ) from the burial site and placed in polypropylene cloth packets (as described before). The seed packets were buried or placed on the soil surface at the Texas A\&M Research Farm, near College Station, immediately after each harvest. These treatments simulate natural field abscission with no fall cultivation or natural field abscission with soil incorporation from early fall cultivation. Packets were buried at $12 \mathrm{~cm}$ in $10 \mathrm{~cm}$ diameter holes or placed on the soil surface between September 14, 1993 and October 30, 1993. The experimental area was maintained undisturbed and vegetation-free with periodic application of glyphosate at $1.12 \mathrm{~kg}$ a.i. $\mathrm{ha}^{-1}$. Seed samples placed on the soil surface were protected from glyphosate application. 
Buried seed samples were recovered in March 1994, October 1994, and March 1995, corresponding approximately to 5, 12 and 17 months after burial. Germination and dormancy tests were conducted on the recovered seed (as described before).

The experimental design was a split-splitplot arrangement in a randomized complete block design with burial depths as the whole plot, harvesting time as subplots and red rice ecotypes/rice cultivars as sub-subplots, with four replications.

\section{Statistical analysis}

Germination and viable seed data of both studies were transformed to the arcsin of the square root (Dowdy \& Wearden, 1983). Data were subjected to statistical analysis using the SAS general linear model (GLM) procedures. When significance was detected, means were separated using Fisher's protected LSD test at the $5 \%$ level of probability.

\section{RESULTS AND DISCUSSION}

\section{Beaumont experiment}

The initial viable seed level of all red rice ecotypes was < 93\% except for TX 2 at $89 \%$ (data not presented). Ecotype TX 1 was the only ecotype with dormant seeds (25\%). Viable seed for the commercial rice was 73 and $77 \%$ for Mars and Lemont, respectively.

Irrigation effect on red rice seed longevity - Viable seed did not differ significantly $(\mathrm{P}>0.05)$ between irrigated and non-irrigated treatments. Therefore, the data from both treatments were pooled. Goss \& Brown (1939, 1940) showed that red rice seed buried in flooded soil had a greater longevity at Stuttgart, AR and Beaumont, TX than it did in California. The lack of irrigation effect on seed longevity in this study could be attributed to the use of small plots $(3 \times 5 \mathrm{~m})$, and irrigated and non-irrigated treatments were located side by side, separated only by earthen levees. This separation may not have been sufficient to isolate the treatment effects.

Effect of burial depth and ecotypes There was a significant $(\mathrm{P}<0.05)$ burial depth by red rice ecotypes/rice cultivars interaction effect on dormancy and germination at all seed recovery times. Viable red rice seed markedly declined for all ecotypes buried for 5 months in the soil, at both soil depths (Table 1). Red rice ecotypes AR 2, LA 2, and MS 2 had less than $1 \%$ viable seeds at the $5 \mathrm{~cm}$ depth. All other ecotypes had no viable seeds remaining at $5 \mathrm{~cm}$ deep. At the first seed recovery (5 months), all red rice ecotypes had viable seeds at the $25 \mathrm{~cm}$ depth. The level ranged from 1 to $21 \%$, with significant differences among ecotypes (Table1). Viable seed for AR 2 buried at $25 \mathrm{~cm}$ was higher than all the other ecotypes (21\%). Lemont and Mars had no viable seeds at either burial depth after 5 months. Although red rice ecotype TX 1 was the only one with dormant seeds (25\%) at burial time (data not presented), variable percentages of viable seeds recovered at the first sampling, in late summer of 1993 were dormant (Tables 1

Table 1 - Red rice ecotype and rice cultivar percent seed viability at burial and after seed recovery from soil depths of 5 and $25 \mathrm{~cm} \mathrm{5,12,17,} \mathrm{24,} 29$ and 36 months after burial near Beaumont, TX

\begin{tabular}{|c|c|c|c|c|c|c|}
\hline \multirow{2}{*}{ Ecotype/cultivar } & \multicolumn{6}{|c|}{ Viable seed-months after burial } \\
\hline & 5 & 12 & 17 & 24 & 29 & 36 \\
\hline $5 \mathrm{~cm}$ & \multicolumn{6}{|c|}{$(\%)$} \\
\hline AR 2 & $<1$ & 0 & 0 & 0 & 0 & 0 \\
\hline LA 2 & $<1$ & $<1$ & 0 & 0 & 0 & 0 \\
\hline LA 4 & 0 & $<1$ & 0 & 0 & 0 & 0 \\
\hline MS 1 & 0 & 0 & 0 & 0 & 0 & 0 \\
\hline MS 2 & $<1$ & 0 & 0 & 0 & 0 & 0 \\
\hline MS 4 & 0 & 0 & 0 & 0 & 0 & 0 \\
\hline MS 5 & 0 & 0 & 0 & 0 & 0 & 0 \\
\hline TX 1 & 0 & 0 & 0 & 0 & 0 & 0 \\
\hline TX 2 & 0 & 0 & 0 & 0 & 0 & 0 \\
\hline Lemont & 0 & 0 & 0 & 0 & 0 & 0 \\
\hline Mars & 0 & 0 & 0 & 0 & 0 & 0 \\
\hline $25 \mathrm{~cm}$ & \multicolumn{6}{|c|}{$(\%)$} \\
\hline AR 2 & 21 & 24 & 5 & 12 & 9 & $<1$ \\
\hline LA 2 & 5 & 4 & 3 & 2 & 1 & $<1$ \\
\hline LA 4 & 6 & 5 & 4 & 3 & 2 & $<1$ \\
\hline MS 1 & 8 & 4 & 2 & 1 & 1 & 0 \\
\hline MS 2 & 6 & 2 & 2 & 1 & $<1$ & 0 \\
\hline MS 4 & 11 & 14 & 5 & 9 & 5 & $<1$ \\
\hline MS 5 & 1 & 0 & 0 & $<1$ & $<1$ & 0 \\
\hline TX 1 & 14 & 14 & 6 & 8 & 10 & $<1$ \\
\hline TX 2 & 2 & 2 & 1 & 2 & 1 & 1 \\
\hline Lemont & 0 & 0 & 0 & 0 & 0 & 0 \\
\hline Mars & 0 & 0 & 0 & 0 & 0 & 0 \\
\hline LSD $(0.05)$ & 4 & 5 & 2 & 4 & 3 & 0.4 \\
\hline
\end{tabular}


and 2). One could speculate that some degree of secondary dormancy was induced during the summer when seeds were placed in an environment unfavorable for germination. Induction of secondary dormancy has been reported in partially imbibed red rice seeds (Garcia-Quiroga, 1987). Benvenuti (2003) reported the induction of secondary dormancy in seeds of Datura stramonium buried at $12 \mathrm{~cm}$.

The decrease in viable seeds buried at $5 \mathrm{~cm}$ was mainly the result of in situ germination during the spring and summer. This was observed at seed recovery by the presence of dead seedlings. Some in situ germination also occurred with seeds buried at $25 \mathrm{~cm}$, but the percentage was much lower. The decrease in viable seed of deeply buried red rice and commercial rice seeds resulted mainly from seed decay.

All ecotypes, except MS 5, had 2 to $24 \%$ seed survival at the $25 \mathrm{~cm}$ depth at 12 months (Table 1). The major difference at this time was that the percentage of dormant seeds had diminished, and seeds germinated when the environment was favorable (Tables 1 and 2).

Viable red rice seeds buried at $25 \mathrm{~cm}$ decreased significantly during the first year. The greatest reductions occurred in spring and summer with a much lower loss during the following months. After two years of burial at $25 \mathrm{~cm}$, ecotypes AR 2, MS 4, and TX 1 still had 12,9 , and $8 \%$ viable seeds, respectively, which was significantly higher than the other ecotypes. Similar to 12 months, viable seeds readily germinated at the 24 month recovery. After thirty-six months buried at $25 \mathrm{~cm}$, all red rice ecotypes had zero or $<1 \%$ viable seeds (Table 1). No significant differences in viable seed were observed for the major groups: blackhull (AR 2, LA 4, TX 2) and strawhull (LA 2, MS 1, MS 2, MS 4, MS 5, TX 1) (Figure 1).

Extreme variability in seed germination and dormancy was observed in the present study at all sampling times. Variability in seed longevity field studies has also been reported by Dawson \& Bruns (1975) who concluded that subtle differences in soil conditions can substantially affect seed survival. Davis et al. (2005) reported that environmental factors like seed depth placement, tillage and abiotic environmental factors affect seed persistence.
Table 2 - Red rice ecotype and rice cultivar percent seed germination after recovery from soil depths of 5 and $25 \mathrm{~cm} \mathrm{5,12,17,24,} 29$ and 36 months after burial near Beaumont, TX

\begin{tabular}{|c|c|c|c|c|c|c|}
\hline \multirow{2}{*}{ Ecotype/cultivar } & \multicolumn{6}{|c|}{ Germination - months after burial } \\
\hline & 5 & 12 & 17 & 24 & 29 & 36 \\
\hline $5 \mathrm{~cm}$ & \multicolumn{6}{|c|}{$(\%)$} \\
\hline AR 2 & 0 & 0 & 0 & 0 & 0 & 0 \\
\hline LA 2 & 0 & 0 & 0 & 0 & 0 & 0 \\
\hline LA 4 & 0 & $<1$ & 0 & 0 & 0 & 0 \\
\hline MS 1 & 0 & 0 & 0 & 0 & 0 & 0 \\
\hline MS 2 & 0 & 0 & 0 & 0 & 0 & 0 \\
\hline MS 4 & 0 & 0 & 0 & 0 & 0 & 0 \\
\hline MS 5 & 0 & 0 & 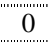 & 0 & (") & 0 \\
\hline TX 1 & 0 & 0 & 0 & 0 & 0 & 0 \\
\hline TX 2 & 0 & 0 & (3) & 0 & (3) & 0 \\
\hline Lemont & 0 & 0 & 0 & 0 & 0 & 0 \\
\hline Mars & 0 & 0 & "ne & 0 & (") & 0 \\
\hline $25 \mathrm{~cm}$ & \multicolumn{6}{|c|}{$(\%)$} \\
\hline AR 2 & 1 & 16 & 3 & 12 & 6 & $<1$ \\
\hline LA 2 & 1 & 1 & 2 & 2 & 1 & $<1$ \\
\hline LA 4 & 4 & 4 & 3 & 3 & 2 & $<1$ \\
\hline MS 1 & 7 & 3 & 2 & 1 & 1 & 0 \\
\hline MS 2 & 2 & 2 & 2 & 1 & $<1$ & 0 \\
\hline MS 4 & 2 & 9 & 3 & 9 & 4 & $<1$ \\
\hline MS 5 & 0 & 0 & 0 & $<1$ & $<1$ & 0 \\
\hline TX 1 & $<1$ & 12 & " & 8 & (3) & $<1$ \\
\hline TX 2 & $<1$ & 2 & $<1$ & 2 & 1 & 1 \\
\hline Lemont & 0 & 0 & 0 & 0 & 0 & 0 \\
\hline Mars & 0 & 0 & 0 & 0 & 0 & 0 \\
\hline LSD $(0.05)$ & 2 & 3 & 2 & 4 & 2 & 0.4 \\
\hline
\end{tabular}

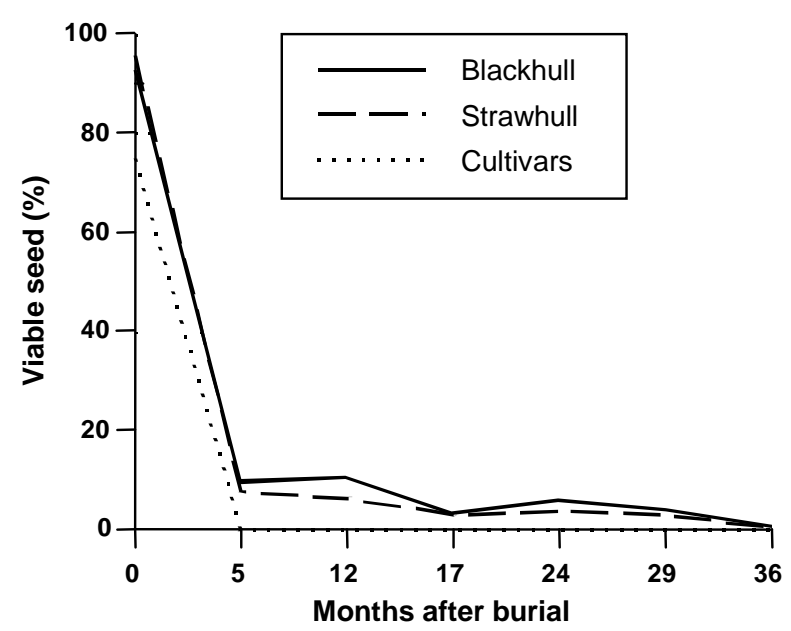

Figure 1 - Seed viability of blackhull and strawhull red rice ecotypes and rice cultivars recovered 5, 12, 17, 24, 29 or 36 months after burial at $25 \mathrm{~cm}$ near Beaumont, TX (study I). Strawhull ecotypes average includes goldhull TX 1 and brownhull MS 4. 


\section{College Station experiment}

Viable seed at harvest - Freshly harvested seed of all ecotypes, harvested 45 days after anthesis, had viability above 88\% (data not presented). In general, the percentage of germination increased, and dormancy decreased as harvest was delayed from 15 to 45 days after anthesis.

Seed longevity in soil - There was a significant $(\mathrm{P}<0.01)$ three-way interaction effect (burial depth $\mathrm{x}$ harvest time $\mathrm{x}$ red rice ecotype/cultivar) for germination and viable seeds recovered at 5 months (Table 3). There was no harvest time effect on viable seed at the 12 and 17 -month recovery times (Table 4). At 17 months, after seeds were in

Table 3 - Red rice ecotype and rice cultivar percent seed viability and germination as affected by burial depth and harvest time (days after anthesis) 5 months after burial near College Station, TX

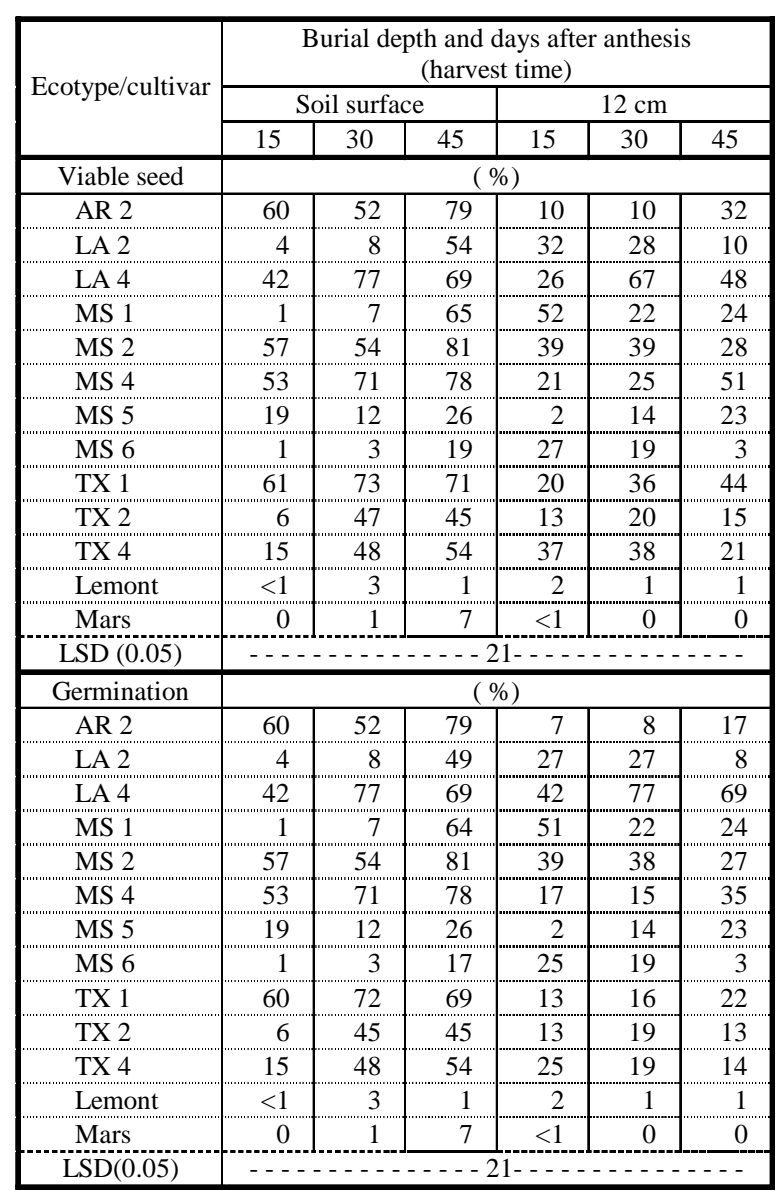

Planta Daninha, Viçosa-MG, v. 24, n. 4, p. 611-620, 2006 the field for two winters, only burial depth significantly $(\mathrm{P}<0.05)$ affected the percentage of viable seed.

After 5 months of burial, rice cultivars Lemont and Mars from all harvest times and burial depths had very low levels of viable seed, ranging from 0 to $7 \%$ (Table 3 ). Seeds of seven of the 11 red rice ecotypes placed on the soil surface had significantly more viable seed when harvested 45 days after anthesis, compared to 15 days after anthesis. The effect of harvest time on viable seed was not significant for AR 2, MS 5, MS 6 and TX 1 when seeds were left on the soil surface. Red rice ecotypes buried at $12 \mathrm{~cm}$ had an overall lower level of viable seed at 5 months than those on the soil surface. The effect of harvest

Table 4 - Red rice ecotype and rice cultivar seed viability and germination as affected by burial depth 12 and 17 months after burial near College Station, TX

\begin{tabular}{|c|c|c|c|c|}
\hline \multirow{3}{*}{ Ecotype/cultivar } & \multicolumn{4}{|c|}{ Months after burial and burial depth } \\
\hline & \multicolumn{2}{|c|}{12 months } & \multicolumn{2}{|c|}{17 months } \\
\hline & Soil surface & $12 \mathrm{~cm}$ & Soil surface & $12 \mathrm{~cm}$ \\
\hline Viable seed & \multicolumn{4}{|c|}{$(\%)$} \\
\hline AR 2 & 0 & 1 & 0 & $<1$ \\
\hline LA 2 & 0 & 4 & "'me & $<1$ \\
\hline LA 4 & 0 & 12 & 0 & 1 \\
\hline MS 1 & 0 & 4 & 0 & $<1$ \\
\hline MS 2 & $<1$ & 11 & 0 & 1 \\
\hline MS 4 & 0 & 6 & 0 & 1 \\
\hline MS 5 & 0 & 1 & 0 & 0 \\
\hline MS 6 & 0 & 1 & 0 & $<1$ \\
\hline TX 1 & 0 & 7 & 0 & $<1$ \\
\hline TX 2 & 0 & 4 & 0 & 2 \\
\hline TX 4 & 0 & 5 & 0 & $<1$ \\
\hline Lemont & 0 & 0 & 0 & 0 \\
\hline Mars & 0 & 0 & 0 & 0 \\
\hline $\operatorname{LSD}(0.05)$ & \multicolumn{2}{|l|}{ (5) } & \multicolumn{2}{|c|}{ (NS) } \\
\hline Germination & \multicolumn{4}{|c|}{ (\%) } \\
\hline AR 2 & 0 & $<1$ & 0 & $<1$ \\
\hline LA 2 & 0 & 4 & 0 & $<1$ \\
\hline LA 4 & 0 & 10 & 0 & 1 \\
\hline MS 1 & 0 & 4 & 0 & $<1$ \\
\hline MS 2 & $<1$ & 8 & 0 & 1 \\
\hline MS 4 & 0 & 6 & 0 & 1 \\
\hline MS 5 & 0 & 1 & 0 & 0 \\
\hline MS 6 & 0 & 1 & "'m & " \\
\hline TX 1 & 0 & 4 & " & < \\
\hline TX 2 & 0 & 3 & 0 & 2 \\
\hline TX 4 & 0 & 4 & 0 & $<1$ \\
\hline Lemont & 0 & 0 & 0 & 0 \\
\hline Mars & 0 & 0 & 0 & 0 \\
\hline $\operatorname{LSD}(0.05)$ & \multicolumn{2}{|l|}{ (4) } & \multicolumn{2}{|c|}{ (NS) } \\
\hline
\end{tabular}


time did not follow any specific trend, but significant differences were observed among red rice ecotypes. The decrease in viable seed after 5 months of burial resulted from in situ seed germination that occurred late in the fall after burial or early in the spring before seed recovery.

The higher level of viable seeds recovered from the soil surface compared to those buried at $12 \mathrm{~cm}$ might be related to soil moisture content early in the spring. At the sampling time, the soil surface as well as the seed packets, were very dry. Conversely, at the $12 \mathrm{~cm}$ depth, the soil was moist, and many freshly germinated seedlings were present at recovery. Most of the viable seeds recovered at 5 months germinated readily in the laboratory (Table 3). The percentage of dormant seeds was very low (0 to 5\%) for all ecotypes on the soil surface, regardless of harvest time. The percentage of seed dormancy was higher for seeds buried at the $12 \mathrm{~cm}$ depth, compared to seeds on the soil surface. Ecotypes AR 2, MS 4, TX 1, and TX 4 had significantly higher seed dormancy when buried at the $12 \mathrm{~cm}$ depth. Dormancy of all ecotypes was partially or totally released early in the spring. Dormancy percentage of seeds buried at $12 \mathrm{~cm}$ and recovered 5 months after burial may not be related to the dormancy level at burial time.

Seed recovered at 12 months after burial showed decreases in viable seed during spring/ summer, and no viable seeds were found at the soil surface, except for ecotype MS 2 which was $<1 \%$ viable seeds (Table 4 ). Overall, red rice seeds buried at $12 \mathrm{~cm}$ had significantly higher levels of viable seed than the ones placed on the soil surface. The percentage of dormant seeds was also very low at the same sampling time (Table 4).

The last recovery in this study took place in March 1995, after seeds had been in the field for two winters (17 months). The percent viable seed was significantly higher at the $12 \mathrm{~cm}$ depth, but when averaged over all ecotypes it was less than 1\%. Ecotype TX 2 had the most viable seed with $2 \%$. No significant differences were observed among ecotypes in seed longevity at 17 months after burial (Table 4). Red rice had greater longevity than the rice cultivars, but no significant differences were detected among red rice ecotypes. Also, no significant differences were detected between blackhull and strawhull ecotypes (Figure 2).

As observed in the Beaumont experiment, considerable variability existed among replications for red rice seed longevity. Variability was greater at the first seed recovery (5 months) and decreased for the following sampling at 12 months.

At Beaumont, red rice longevity was greater with burial depth, and at College Station, buried red rice seed lasted longer than the ones placed on soil surface. Greater decreases in viable seed at shallower depths have also been reported for other weed species (Burnside et al., 1996; Dawson \& Bruns, 1975; Miller \& Nalewaja, 1990; Taylorson, 1987). More rapid declines in longevity of seeds placed at shallow depths have been attributed to greater environmental fluctuations (Pickett, 1989; Taylorson, 1987) favoring higher percentage seed germination (Dawson \& Bruns, 1975). Repeated seed desiccation by alternate hydration and dehydration probably enhanced dormancy release and stimulated germination of red rice seed placed on the soil surface or buried at a shallow depth (Berrie \& Drennan, 1971; Martinez-Ghersa et al., 1997;

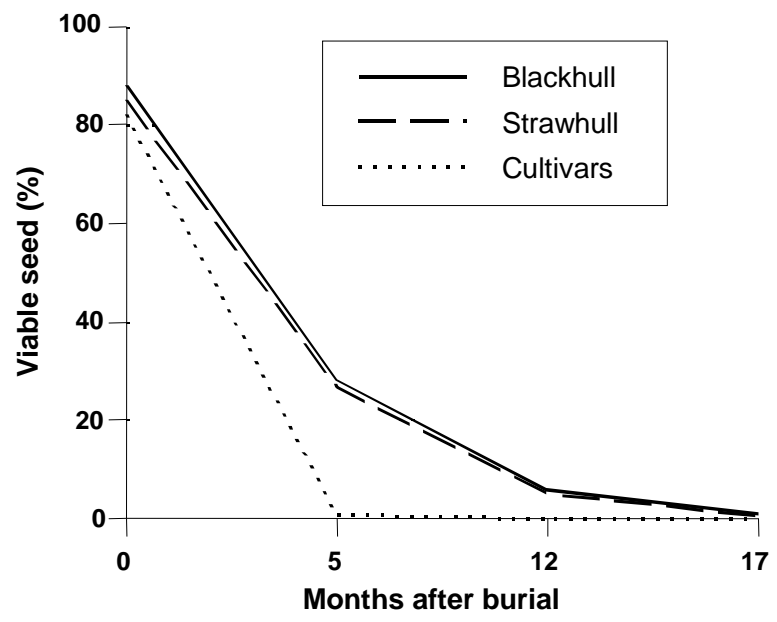

Figure 2 - Seed viability of blackhull and strawhull red rice ecotypes and rice cultivars recovered 5,12 or 17 months after burial at $12 \mathrm{~cm}$ near College Station, TX (study II). Strawhull ecotypes average includes goldhull TX 1 and brownhull MS 4. 
Simpson, 1990; Vincent \& Cavers, 1978). This may help to explain why seeds harvested later after anthesis, with lower seed moisture content and a lower dormancy, tended to have higher percent viable seed in the spring.

Non-dormant red rice seeds buried at $25 \mathrm{~cm}$ in Beaumont had greater longevity than dormant seeds buried at $12 \mathrm{~cm}$ in College Station. The percent of viable seeds buried at $5 \mathrm{~cm}$ in Beaumont or placed on soil surface in College Station was approximately zero after one year for all ecotypes and cultivars. Differences were significant for deeply buried seeds. At Beaumont, seeds at the $25 \mathrm{~cm}$ depth were located in a very flat area with a higher water table than in College Station. Under those conditions, seeds were exposed to much higher soil moisture, and lower oxygen concentration (Egley, 1986; Smith \& Dowdell, 1974), during most of the burial period. These conditions are less favorable to germination (Honěk \& Martinková, 1992; Ikehashi, 1975; Taylorson, 1987) and may be beneficial to seed longevity of species of wet grassland communities (Bekker et al., 1998). At College Station, seeds buried at the $12 \mathrm{~cm}$ depth were in more permeable soil, and oxygen concentration was probably not limiting for germination (Smith \& Dowdell, 1974).

Many reports (Chancellor, 1982; Kivilaan \& Bandurski, 1973; Roberts, 1972; Taylorson, 1970) suggest that there is an association between seed dormancy and longevity in the soil. However, this may not always be the case (Simpson, 1990), especially for rice (Juliano et al., 1990; Roberts, 1963). These authors reported no association between dormancy and seed longevity in several rice cultivars stored under the same environmental conditions. Results of this research suggest that red rice seed longevity in the soil is not correlated with seed dormancy at burial time.

Differences in seed longevity among red rice ecotypes was not significant at College Station, but under Beaumont conditions, ecotypes AR 2, MS 4, and TX 1, had significantly greater longevity when placed deeper in the soil. However, viable seed for ecotypes AR 2, MS 4, and TX 1, after 24 months of deep burial, was much lower than that reported by Goss \& Brown (1939). They found that after seeds were buried two years at
Beaumont, the average level of viable seed of three southern red rice populations was 36 and $66 \%$, for nonirrigated and irrigated treatments, respectively. The shorter longevity observed in our study is probably related to the lack of dormancy of most red rice ecotypes when seeds were buried or due to variation between ecotypes. Red rice populations present in rice fields in the 1930's probably had different genetic make-up compared to those infesting rice fields during the last two decades. Many red rice ecotypes have characteristics closely related to rice cultivars, resulting in less adaptation to soil longevity. For example, strawhull ecotype MS 5, which has several plant characters common to rice cultivars, had seed longevity similar to rice cultivars at Beaumont.

These studies fully support the recommendation for rice producers to avoid deep tillage practices such as ploughing after harvesting a crop infested with red rice. Deep tillage places seeds deeper in the soil and in an environment less favorable for germination, thus increasing longevity. After harvest, highly intensive rice production systems, i.e., rice planted in monoculture in the same area, tillage of infested fields should be delayed until the following spring. Using this method red rice seeds shed on soil surface would germinate either late in the fall or early in the spring before planting the new crop. Rotation crops after rice using shallow or reduced tillage systems would also favor red rice germination reducing seed population significantly in one year. Regardless of the system used, it is important that germinated seedlings might be controlled before flowering to avoid seed production and future reinfestation. These data suggest that 2-3 years of no red rice seed production would eliminate nearly all red rice plants since no seed would replenish the seed bank.

\section{ACKNOWLEDGMENTS}

We thank the following persons for providing the initial seed source of most red rice ecotypes evaluated in this study: Dr. James C. Delouche, Seed Technology Laboratory, Mississippi State University, Mississippi State; Dr. James L. Griffin, Dept. Plant Pathology and Crop Physiology, Louisiana State University, 
Baton Rouge; Dr. Roy J. Smith, Jr. (deceased), U.S. Department of Agriculture, Stuttgart, AR; and Dr. Charlie Grymes, former Graduate Student at Soil and Crop Science Dept., Texas A\&M University, College Station.

\section{LITERATURE CITED}

BASKIN, J. M.; BASKIN, C. C. The annual dormancy cycle in buried weed seeds: a continuum. Bioscience, v. 35, p. 492-498, 1985.

BENVENUTI, S. Soil texture involvement in germination and emergence of buried seeds. Agron. J., v. 95, p. 191-198, 2003.

BEKKER, R. M. et al. The impact of groundwater level on soil seed bank survival. Seed Sci. Res., v. 8, p. 399-404, 1998.

BERRIE, A. M. M.; DRENNAN, D. S. H. The effect of hydration-dehydration on seed germination. New Phytol., v. 70 , p. $135-142,1971$.

BURNSIDE, O. C. et al. Seed longevity of 41 weed species buried 17 years in Eastern and Western Nebraska. Weed Sci., v. 44, p. 74-86, 1996.

CHANCELLOR, R. J. Dormancy in weed seeds. Outlook Agric., v. 11, p. 87-93, 1982.

CONN, J. S.; DECK, R. E. Seed viability and dormancy of 17 weeds species after 9.7 years of burial in Alaska. Weed Sci., v. 43, p. 583-585, 1995.

DAVIS, A. S. et al. Environmental factors affecting seed persistence of annual weeds across the U.S. corn belt. Weed Sci., v. 53, p. 869-868, 2005.

DAWSON, J. H.; BRUNS, V. F. Longevity of barnyardgrass, green foxtail, and yellow foxtail seeds in soil. Weed Sci., v. 23 , p. $437-440,1975$.

DOWDY, S.; WEARDEN, S. Statistics for research. New York: John Wiley \& Sons, 1983. 537 p.

EGLEY, G. H. Simulation of weed seed germination in soil. Rev. Weed Sci., v. 2, p. 67-89, 1986.

EGLEY, G. H.; CHANDLER, J. M. Longevity of weed seeds after 5.5 years in the Stoneville 50-year buried-seed study. Weed Sci., v. 31, p. 264-270, 1983.

EGLEY, G. H.; WILLIAMS, R. D. Decline of weed seeds and seedling emergence over five years as affected by soil disturbances. Weed Sci., v. 38, p. 504-510, 1990.
GARCIA-QUIROGA, E. Release and induction of dormancy in seeds of red rice (Oryza sativa L.) in the field and laboratory. 1987. 95 f. Thesis (Ph.D.) - Mississipi State University, 1987.

GOSS, W. L.; BROWN, E. Buried red rice seed. J. Am. Soc. Agron., v. 31, p. 633-637, 1939.

GOSS, W. L.; BROWN, E. Buried red rice seed. J. Am. Soc. Agron., v. 32, p. 974, 1940.

HONěK, A.; MARTINKOVÁ, Z. The induction of secondary seed dormancy by oxygen deficiency in a barnyardgrass Echinochloa crus-galli. Experientia, v. 48, p. 904-906, 1992.

IKEHASHI, H. Dormancy formation and subsequent changes of germination habits in rice seeds. J. Agric. Res. Quarter, v. 9, p. 8-12, 1975.

JULIANO, B. O.; PEREZ, C. M.; CHANG, T. T. Varietal differences in longevity of tropical rough rice stored under ambient conditions. Seed Sci. Technol., v. 18, p. 361-369, 1990.

KIVILAAN, A.; BANDURSKI, R. S. The ninety-year period for Dr. Beal's seed viability experiment. Am. J. Bot., v. 60, p.140-145, 1973.

LEWIS, J. Longevity of crop and weed seeds: survival after 20 years in soil. Weed Res., v. 13, p. 179-191, 1973.

MARTINEZ-GHERSA, M. A.; SATORRE, E. H.; GHERSA, C. M. Effect of soil water content and temperature on dormancy breaking and germination of three weeds. Weed Sci., v. 45, p. 791-797, 1997.

MILLER, D. S.; NALEWAJA, J. D. Influence of burial depth on wild oats (Avena fatua) seed longevity. Weed Technol., v. 4, p. 514-517, 1990.

OVERAA, P. Distinguishing between dormant and inviable seeds. In: DICKIE, J. B. et al. (Eds.). Seed management techniques for genebanks: Report of a Workshop Held at Royal Botanic Gardens. Rome: Board Plant Genetic Resources, 1984. p. 182-196.

PICKETT, A. A. A review of seed dormancy in self-sown wheat and barley. Plant Var. Seeds, v. 2, p. 131-146, 1989.

ROBERTS, E. H. An investigation of inter-varietal differences in dormancy and viability of rice seed. An. Bot., v. 27 , p. $365-369,1963$.

ROBERTS, E. H. Dormancy: a factor affecting seed survival in the soil. In: ROBERTS, E. H. (Ed.). Viability of seeds. Syracuse: University Press, Syracuse, 1972. p. 321-359.

SIMPSON, G. M. Seed dormancy in grasses. Cambridge: Cambridge University Press, 1990. 297 p. 
SMITH, K. A.; DOWDELL, R. J. Field studies of the soil atmosphere. I. Relationships between ethylene, oxygen, soil moisture content, and temperature. J. Soil Sci., v. 25, p. 217-230, 1974.

TAYLORSON, R. B. Changes in dormancy and viability of weed seeds in soils. Weed Sci., v. 18, p. 265-269, 1970.

TAYLORSON, R. B. Environmental and chemical manipulation of weed seed dormancy. Rev. Weed Sci., v. 3, p. 135-154, 1987.

TELEWSKI, F. W.; ZEEVAART, J. A. D. The 120 -yr period for Dr. Beal's seed viability experiment. Am. J. Bot., v. 89, n. 8, p. 1285-1288, 2002.
TOOLE, E. H.; BROWN, E. Final results of the Duvel buried seed experiment. J. Agric. Res., v. 72, p. 201-210, 1946.

VINCENT, E. M.; CAVERS, P. B. The effects of wetting and drying on the subsequent germination of Rumex crispus.

Can. J. Bot., v. 56, p. 2207-2217, 1978.

YOSHIDA, S. Growth and development of the rice plant. In: YOSHIDA, S. (Ed.). Fundamentals of rice crop science. Los Baños: The Internacional Rice Research. Institute, 1981. p. 1-61.

ZORNER, P. S.; ZIMDAHL, R. L.; SCHWEIZER, E. E. Effect of depth and duration of seed burial on kochia (Kochia scoparia). Weed Sci., v. 32, p. 602-607, 1984. 